\title{
PENDEKATAN RASIONAL DALAM DAKWAH MASYARAKAT MODERN KONTEKS INDONESIA
}

\author{
Suwari \& Dedy Pradesa \\ STID Al-Hadid, Surabaya \\ suwari.adv@gmail.com \& depra19312@gmail.com
}

\begin{abstract}
Abstrak: Studi ini dilatarbelakangi pengamatan penulis terhadap fenomena dakwah di Indonesia yang normatif atau kurang menampilkan pendasaran keilmuan dan sosiologis/rielnya dalam penyajian pesan dan metode dakwah. Islam mengajarkan rasional, maka dakwah harus didekati secara rasional. Terlebih saat ini adalah era modern dan globalisasi. Studi ini memfokuskan pada penyajian pesan dan metode dakwah dengan pendekatan rasional dalam dakwah masyarakat modern konteks Indonesia. Metodologi yang digunakan pustaka kualitatif. Hasil studi menunjukkan karakteristik masyarakat modern Indonesia sejalan dengan ciri manusia modern, namun beragam. Modernisme yang dilaksanakan ternyata membawa dampak positif dan negatif, sehingga menjadi problematika sosial. Berpijak pada asumsi tersebut maka pesan dakwah pada masyarakat modern haruslah disajikan secara rasional, dengan pertanggungjawaban, dan berpijak pula pada ilmu pengetahuan terkait. Pesan dakwah perlu disajikan secara sistematis dan terkurikulum. Prioritas isi pesannya adalah tema ketauhidan, nilai berpikir dan ilmu pengetahuan, kebangsaan, serta menjawab berbagai persoalan kehidupan yang senantiasa berkembang, bukan hanya membahas fikih, ibadah, dan yang berorientasi masa lalu. Adapun metode dakwahnya dapat menggunakan berbagai alternatif metode, yang terpenting adalah membuka ruang dialog, serta menghindari doktrin dan pemaksaan. Implementasi metode dakwah harus memperhatikan etika dakwah, diantaranya tidak dengan segala cara, penghujatan, dan kekerasan, melainkan menampilkan dakwah yang santun dan sejuk, dengan tetap mengedepankan nilainilai persatuan bangsa.
\end{abstract}

Kata Kunci: pesan dakwah, metode dakwah, pendekatan rasional, masyarakat modern, Indonesia

Rational Approach in Da'wah to Modern Society in Context of Indonesia. Abstract: This study is motivated by auhthor's observation of da'wah phenomenon in Indonesia that's normative or lacks scientific knowledge and sociological/reality especially in presenting da'wah message and its method. Islam teaches rationality. Therefore, da'wah needs to be approached rationally. Its emphasizes on presenting da'wah message and its rational method in propagating Indonesian modern society. This study method is qualitative literature. It results that the characteristics of Indonesian modern society are in line with the ones of modern society. In fact, the modernism brings positive and negative impacts, emerging social problems. Standing on the assumption, da'wah messages must be designed in a curriculum, presented rationally, responsibly, systematically, and related to science as well. Priorities of their contents are around issues of the oneness of God, rational value and science, nationalities, and solving various life issues which progressively develop. They should not boundaries its scope on fiqh, rituals, dan past-time oriented things. Da'wah can apply alternative methods, that the most important thing is to provide dialogues, avoid doctrine, or coercion. Da'wah method implementation should concern on its ethics. It should not be conducted by Machiavellian way, humiliation, and violence. Instead, it should present polite and peaceful da'wah and emphasize on the values of national unity. 
Keywords: da'wah message, da'wah method, rational approach, modern society, Indonesia

\section{Pendahuluan}

Dakwah pada hakikatnya mengajak dan menawarkan gagasan ajaran Islam kepada mitra dakwah sebagai pasar. Islam adalah agama yang rasional. Dalam ajaran Islam, akal mempunyai kedudukan yang tinggi dan banyak dipakai, bukan hanya dalam rangka pengembangan ilmu pengetahuan dan kebudayaan masyarakat, melainkan pengembangan ajaran Islam itu sendiri. ${ }^{1}$ Dalam Alquran, Allah mewajibkan penggunaan akal untuk memecahkan berbagai masalah kehidupan. ${ }^{2}$ Maka kegiatan dakwah, baik dalam pesan maupun cara-caranya, harus dilaksanakan dengan berbasis rasional, tidak boleh mematikan potensi akal pikiran umat Islam. Ali Aziz menyatakan bahwa ajaran Islam yang menjadi pesan dakwah adalah ajaran rasional, maka sudah seharusnya pesan dakwah yang rasional disampaikan dengan cara rasional pula. $^{3}$ Realitasnya terdapat pesan-pesan dakwah yang irasional, berbau mistik atau tahayul, mengandung unsur kebohongan (hoax) dan manipulatif, berisi doktrin tanpa pertanggungjawaban yang berkembang di masyarakat. Sebagai contoh dakwah yang dikemas melalui media film atau sinetron religi, kerap kali bermuatan hal-hal yang tidak masuk akal, dan berbau tahayul. Abdul Basit menjelaskan beberapa permasalahan dakwah sinetron, di

\footnotetext{
1 Harun Nasution, Akal dan Wahyu dalam Islam, (Jakarta: UI Press, 1986), 101.

2 Iskandar Al-Warisyi, Kedudukan Akal dan Wahyu dalam Islam, (Surabaya: Penerbit Yayasan Al-Kahfi, 2012), 44-45.

3 Moh. Ali Aziz, Ilmu Dakwah Edisi Revisi, (Jakarta: Kencana, 2016), 98-100.
}

antaranya secara tema masih berkutat pada penghukuman Allah atas pendosa, yang sayangnya kejadian (hukuman) itu belum jelas dasarnya, sebagiannya bersifat sinkretis (penggabungan unsur mistik dan agama), dan banyak cerita-cerita aneh yang sulit diterima secara logika. ${ }^{4}$ Demikian pula dalam dakwah yang memanfaatkan media internet melalui aplikasi sosial media seperti facebook, instagram, twitter, dan youtube, tidak jarang memuat pesan-pesan dakwah yang mengandung hoax dan tidak bisa dipertanggungjawabkan. ${ }^{5}$ Belum lagi ajaran Islam yang ditampilkan sebagai dogma, dan keyakinan semata, dalam kegiatan ceramah, tablig, dan sejenisnya, umat bahkan dilarang mempertanyakan atau memikirkannya. Pesan dakwah yang disajikan secara irasional justru berdampak negatif terhadap ajaran Islam, karena akan dipandang sebagai ajaran yang tidak ilmiah, jumud, dan identik dengan kebodohan. Islam akan ditinggalkan oleh masyarakat modern manakala tidak ditampilkan sebagaimana aslinya sebagai agama yang rasional.

Cara-cara dakwah yang tidak rasional di antaranya ditunjukkan dengan penggunaan metode dakwah yang bersifat koersif (memaksa), kekerasan fisik maupun psikis, komunikasi yang menghujat, menjatuhkan, dan mendiskreditkan, serta dakwah dengan

\footnotetext{
${ }^{4}$ Abdul Basit, "Dakwah Cerdas di Era Modern," Jurnal Komunikasi Islam, Volume 03, Nomor 01, (Juni 2013): 90-91.

${ }^{5}$ Bagus Wira Prasetia, "Metode Komunikasi Dakwah pada Media Sosial (Facebook, Youtube, Twitter, dan Instagram)," Jurnal Kajian dan Pengembangan Manajemen Dakwah, Volume 08, Nomor 02, (Desember 2018): 408.
} 
segala cara (fitnah). Fenomena dakwah gerakan Islam transnasional di Indonesia dapat menjadi indikasi betapa cara dakwah yang tidak rasional telah berkembang di masyarakat modern Indonesia. Dalam buku Ilusi Negara Islam, dijelaskan bahwa gerakan Islam transnasional di Indonesia mengembangkan metode dakwah yang lekat dengan kekarasan doktrinal, kultural, dan sosiologis. Kekerasan doktrinal yang dimaksud adalah mendakwahkan pemahaman Islam literal dan tertutup atas teks-teks keagamaan, dan hanya menerima kebenaran sepihak. Dampaknya adalah melahirkan kekerasan kultural, yaitu mudahnya memvonis musyrik, murtad, bahkan kafir kepada umat Islam yang tidak sepaham. Dampak selanjutnya adalah adanya aksi-aksi anarkis dan destruktif terhadap pihak-pihak yang dituduh musyrik, murtad, dan kafir. Kekerasan sosial tersebut menyebabkan instabilitas dan kegelisahan sosial. Akumulasi dari ketiga kekerasan tersebut adalah merusak nalar dan logika umat Islam dan menyuburkan kesalahkaprahan dalam memahami ajaran Islam. ${ }^{6}$ Fenomena pemaksaan dakwah juga terjadi di suatu organisasi dakwah pelajar. Pelajar sebagai mitra dakwah dipaksa untuk memilih hanya mengikuti kajian organisasinya atau kajian organisasi dakwah lain, yang dianggap sebagai kompetitornya. ${ }^{7}$ Jika metode koersif terus digunakan maka akan menyebabkan masyarakat mengikuti Islam karena merasa takut, bukan karena menyadari kebenaran ajaran Islam. ${ }^{8}$

\footnotetext{
6 Abdurrahman Wahid (Ed.), Ilusi Negera Islam Ekspansi Gerakan Islam Transnasional di Indonesia, (Jakarta: The Wahid Institute, 2010), 88-89.

7 Ahmad Hidayat, "Efek Dakwah Persuasif," Jurnal Kajian dan Pengembangan Manajemen Dakwah, Volume 02, Nomor 01, (Juni, 2012): 40-41.
}

Pemaksaaan, kekerasan, dan doktrin adalah cara-cara dakwah yang tidak rasional, sebab tidak menumbuhkan kesadaran pada mitra dakwah, dan jelas makin memperburuk citra Islam di mata publik. Basit menengarai bahwa munculnya kekerasan-kekerasan yang dilakukan atas nama agama, adalah karena lemahnya kajian-kajian dakwah di kalangan umat Islam, karena basis keilmuannya yang kurang kokoh, sehingga dakwah berjalan apa adanya tanpa ada desain yang teratur dan sistematis. ${ }^{9}$ Dengan kata lain dakwah yang ada, tidak dilaksanakan dengan pendekatan rasional. Ajaran Islam sebagai pesan dakwah tidak dipahami secara rasional. Akibatnya disajikan dalam bentuk produk dakwah yang tidak rasional pula. Islam dipandang sebagai keyakinan semata, bahkan cenderung mistis dan tahayul. Metode dakwah yang dikembangkan juga tidak memiliki basis rasional yang kuat. Jadilah cara-cara pemaksaan, klaim, hujatan, dan kekerasan dalam dakwah. Sehingga tidak mengherankan jika dakwah Islam di Indonesia sampai dengan saat ini relatif berjalan di tempat dan tidak banyak menunjukkan kemajuan yang signifikan.

Padahal jika menilik perkembangan masyarakat Indonesia yang tengah memasuki era modern dan globalisasi maka pendekatan dakwah yang tidak rasional sebagaimana fenomena di atas, akan tidak lagi relevan. Giddens mengemukakan bahwa modernisasi merupakan sebuah keharusan yang tidak bisa ditolak kehadirannya dan menjadi bagian dari perjalanan yang akan

\footnotetext{
${ }^{8}$ Ibid., 40-41.

${ }_{9}^{9}$ Abdul Basit, Filsafat Dakwah, (Jakarta: Rajagrafindo Persada, 2013), 15.
} 
dilalui oleh peradaban manusia. ${ }^{10}$ Modernisasi menuntut penyesuaian pola pikir, sikap, dan mentalitas dengan perkembangan zaman, termasuk dalam cara-cara berdakwah yang harus disesuaikan dengan karakteristik masyarakat modern. Schrool mengutarakan gejala umum masyarakat modern dapat dirumuskan sebagai penerapan pengetahuan ilmiah kepada semua sektor kehidupan masyarakat, tidak hanya terbatas pada pengetahuan teknik atau ekonomi, ${ }^{11}$ sehingga masyarakat modern memiliki pola pikir yang lebih terbuka dan rasional.

Pendekatan dakwah yang irasional, penuh doktrin, pemaksaan, apalagi penggunaan kekerasan sangat tidak cocok dengan karakter masyarakat modern. Sebaliknya dakwah yang didekati dengan rasionalitas dan berbasis ilmu pengetahuan adalah ciri dari dakwah modern, oleh karenanya sangat sejalan dengan perkembangan zaman di alam modern. Terlebih kini kemajuan teknologi informasi telah mengglobal, informasi tentang ajaran Islam tidak lagi hanya bisa didapatkan melalui kegiatan ceramah-ceramah keagamaan, tetapi masyarakat modern dapat mengakses berbagai media sosial dan internet untuk mendapatkan informasi dan pengetahuan keagamaan. Sebagaimana diungkap Masdar Hilmy, bahwa jika mengharapkan dunia dakwah tidak kehilangan elan vitalitasnya di era informasi ini, maka perubahan pendekatan dan strategi dakwah menjadi suatu hal yang tidak bisa ditawar lagi, hanya

\footnotetext{
${ }^{10}$ Anthony Giddens, The Consequences of Modernity, (California: Stanford University Press, 1990), 39.

11 J. W. Schoorl, Modernisasi Pengantar Sosiologi Pembangunan Negara-Negara Sedang Berkembang, diterjemahkan R.G. Soekadijo, (Jakarta: Gramedia Pustaka Utama, 1991), 4-5.
}

bertumpu pada metode dakwah konvensional jelas tidak realistis. ${ }^{12}$ Dakwah pendekatan rasional dapat menjadi solusi dakwah di era informasi. Di tengah derasnya arus informasi tersebut, termasuk informasi keagamaan (pesan dakwah), dibutuhkan kepekaan dan kemampuan berpikir kritis dari umat Islam untuk menelaah tiap pesan dakwah yang disajikan.

Dibalik kemajuan masyarakat modern Indonesia, berbagai persoalan seperti ketimpangan ekonomi, konflik sosial, etika politik segala cara, perilaku koruptif, kebebasan dan penyimpangan seksual, menjadi sebuah patologi yang mengancam keberlangsungan hidup masyarakat. Dakwah sebagai salah satu sistem sosial dapat menjadi sistem penyembuh patologi sosial. Sebagaimana ditegaskan Al-Warisyi, bahwa dakwah pada suatu masyarakat, seperti konsep terapi pada kesehatan, disamping sifatnya harus benar, juga berfungsi sebagai penyembuh, pembaik terhadap suatu yang rusak. ${ }^{13}$ Salah satu problematika yang muncul dalam masyarakat modern adalah kerawanan moral dan etika, sebagai ekses dari kemajuan teknologi informasi dan komunikasi. Menghadapi kompleksitas masalah masyarakat yang demikian, tidak mungkin dilaksanakan dengan cara-cara dakwah yang biasa, apalagi dengan pemaksaan dan kekerasan. Dalam hal ini perlu ada usaha untuk menghadirkan nilai Islam yang lebih aplikatif, kontributif, dan kontekstual. Para pelaku dakwah mesti

\footnotetext{
12 Masdar Hilmy, Islam Profetik - Substansi Nilai-Nilai Agama dalam Ruang Publik, (Yogyakarta: Kanisius, 2008), 97.

${ }^{13}$ Iskandar Al-Warisyi, Dakwah Illahiyah: Jalan dakwah Tujuh Rasul Allah dalam Memperbaiki Masyarakat Jahiliyah, (Surabaya: Penerbit Yayasan Al-Kahfi, 2009), 3.
} 
keluar dari kebiasaan lama yang menganggap dakwah sebagai doktrin, berkoar-koar di mimbar, serta mengajak masyarakat berbuat baik tanpa memahami konteks permasalahan yang dihadapi. ${ }^{14}$ Pendekatan yang aplikatif, kontributif, dan kontekstual dapat dilaksanakan manakala dakwah didekati secara rasional.

Dari uraian di atas dapat disimpulkan bahwa pendekatan rasional dalam dakwah sangat mendesak untuk dilaksanakan. Urgensi dakwah pendekatan rasional tidak hanya karena secara normatif Islam adalah agama yang rasional, namun secara sosiologis, masyarakat yang dihadapi dakwah Islam saat ini adalah masyarakat modern yang mengglobal, dengan kompleksitas permasalahan yang melingkupinya. Dalam Kamus Besar Bahasa Indonesia (KBBI) pendekatan diartikan sebagai proses, cara, perbuatan mendekati. Pendekatan ilmiah berarti penggunaan teori suatu bidang ilmu untuk mendekati suatu masalah. ${ }^{15}$ Sedangkan rasional dalam KBBI adalah menurut pikiran dan pertimbangan yang logis, pikiran yang sehat, cocok dengan akal. $^{16}$ Pendekatan rasional berarti penggunaan akal pikiran dan pertimbangan yang logis untuk mendekati suatu masalah. Pendekatan dakwah diartikan oleh Aziz sebagai titik tolak atau sudut pandang terhadap proses dakwah. Pendekatan itulah yang melahirkan strategi, metode, teknik, dan taktik. ${ }^{17}$ Sehingga pendekatan rasional dalam dakwah berarti penggunaan akal untuk mendekati permasalahan dakwah. Rasio menjadi titik tolak atau sudut pandang

14 Ihsan Rahmat dan Bayu Mitra A. Kusuma, "Menembus Batas Kajian Doktrinal" Pengantar Editor dalam M. Rosyid Ridla, Afif Rifa'i, dan Suisyanto, Pengantar Ilmu Dakwah: Sejaarah, Perspektif, dan Ruang Lingkup, (Yogyakarta:Samudra Biru, 2017), vi. ${ }^{15} \mathrm{KBBI}$ versi online/daring, kbbi.web.id./dekat.html. terhadap proses metodologi dakwah. Dengan pendekatan rasional akan melahirkan strategi, metode, teknik, dan taktik yang berbasis rasional pula. Adapun masyarakat modern dalam studi ini tidak hanya dibatasi pada masyarakat era industri tetapi melingkupi situasi kontemporer masyarakat yang kini disebut sebagai era globalisasi dan informasi.

Telah cukup banyak studi terdahulu yang membahas bagaimana dakwah menghadapi situasi masyarakat modern dan globalisasi, baik dalam tataran paradigma, strategi, atau metode, di antaranya adalah, pertama, artikel jurnal ilmiah berjudul "Paradigma Dakwah Upaya Merespon Problematika Umat Islam di Era Modern." Artikel tersebut berangkat dari persoalan krusial menipisnya ruang religiusitas sebagai salah satu dampak modernisasi dan globalisasi. Sementara proses dakwah selama ini cenderung mengarah pada konsep komunikasi ala perbankan. Untuk itu studi tersebut menawarkan konsep strategi dakwah dalam merespon problematika umat, di antaranya adalah menyangkut kualifikasi dai yang lemah lembut, toleran, santun, dan memberikan kemudahan; kembali pada Alquran dan Sunnah bukan mahzab, dan sebagainya. ${ }^{18}$ Kedua, artikel jurnal ilmiah berjudul "Dakwah Cerdas di Era Modern." Artikel tersebut berupaya menjelaskan bagaimana cara berdakwah yang cerdas di era modern, dan berpendapat bahwa ada empat hal yang bisa dilakukan dalam berdakwah di era kontemporer, yakni menjadikan dakwah sebagai objek ilmu,

${ }^{16} \mathrm{KBBI}$ versi online/daring, kbbi.web.id./rasional.html.

${ }_{17}$ Aziz, Ilmu Dakwah., 347.

18 Istina Rakhmawati, "Paradigma Dakwah Upaya Merespon Problematika Umat Islam," At-Tabsyir: Jurnal Komunikasi Penyiaran Islam, Volume 3, Nomor 2, (Desember, 2015). 
mengubah paradigma ilmu dakwah menjadi ilmu komunikasi Islam, menyiapkan dai yang mampu beradaptasi dengan perkembangan iptek, dan memanfaatkan berbagai media komunikasi dan informasi. ${ }^{19}$ Ketiga, artikel jurnal ilmiah berjudul "Dakwah Dinamis di Era Modern (Pendekatan Manajemen Dakwah)." Artikel tersebut menggagas konsep dakwah dinamis sebagai sebuah pendekatan dalam dakwah di era modern. Dakwah dinamis bisa dilakukan dengan memanfaatkan media teknologi dan informasi, melihat keadaan masyarakat yang sebenar-benarnya (berdasarkan kondisi yang nyata), dan mencari metode baru yang lebih menarik dan tepat untuk dilakukan dalam kegiatan dakwah. ${ }^{20}$ Keempat, artikel jurnal ilmiah berjudul "Keteladanan sebagai Dakwah Kontemporer dalam Menyongsong Masyarakat Modern." Artikel tersebut bertujuan menggali penerapan keteladanan sebagai bentuk dakwah kontemporer. Dakwah dengan keteladanan di antaranya adalah mampu meneladani masyarakat dalam menapak jejak kemuliaan hidup, mampu memotivasi dan memfasilitasi masyarakat untuk hidup teratur dan jauh dari polusi yang merusak nuraninya, menghasilkan produk kebudayaan yang tinggi, mampu menjembatani kesenjangan diametral antara berbagai orientasi, dan menjadi solusi dan mampu mengimbangi berbagai tawaran informasi nondakwah. ${ }^{21}$

Berdasarkan penelusuran studi terdahulu di atas, diketahui terdapat beberapa alternatif metodologi dakwah untuk menghadapi situasi masyarakat modern dan era globalisasi, baik dalam tataran paradigma,

\footnotetext{
19 Basit, "Dakwah Cerdas."

20 Nur Alhidayatillah, "Dakwah Dinamis di Era Modern," Jurnal An-Nida', Volume 41, Nomor 2, (Desember, 2017).
}

strategi, maupun metode. Pada prinsipnya semua studi terdahulu menyepakati bahwa perubahan situasi masyarakat modern perlu disikapi dengan cara-cara dakwah yang baru atau lebih adaptif. Hanya titik tolaknya yang berbeda, ada yang melihat perlunya perubahan paradigmatik dalam dakwah modern, pendekatan dan strategi yang menekankan pada pemanfaatan dan penguasaan teknologi informasi, kualifikasi dai yang lebih sesuai, penguasaan iptek, serta moral keteladanan dalam dakwah. Belum ada satu studi pendekatan dakwah pada konteks masyarakat modern yang didekati dengan secara rasional, sebagaimana yang dikaji dalam studi ini. Dengan demikian posisi studi ini adalah melengkapi khazanah metodologi dakwah untuk menghadapi masyarakat modern. Titik tolak yang digunakan adalah realitas pesan dan cara dakwah yang tidak rasional, yang itu bertentangan dengan ajaran Islam yang rasional.

Studi ini bertujuan untuk mengembangkan pendekatan rasional dalam dakwah pada masyarakat modern kontemporer Indonesia. Fokus studi dibatasi pada bagaimana pendekatan rasional dalam penyajian pesan dan metode dakwah pada konteks masyarakat modern. Kerangka teoritik yang berpijak pada konsep rasionalitas dakwah Islam, dan teori pesan dan metode dakwah. Metodologi studi ini adalah pustaka analitik, dengan unit analisis penyajian pesan dan metode dakwah yang rasional dalam masyarakat modern kontemporer konteks Indonesia. Data-data terkait konteks masyarakat modern

\footnotetext{
21 Hasan Bastomi, "Keteladanan sebagai Dakwah Kontemporer dalam Menyongsong Masyarakat Modern," Komunika, Volume 11, Nomor 1, (Januari Juni 2017).
} 
Indonesia kontemporer dikumpulkan melalui pembacaan secara cermat dan triangulasi terhadap sumber-sumber kepustakaan terkait. Analisis data dilakukan secara interaktif dan berlangsung secara terus menerus sampai tuntas, dengan tiga aktivitas utama, yaitu reduction, data display, dan conclusion drawing/verification. ${ }^{22}$

\section{Rasionalitas Dakwah Islam}

Rasionalitas dalam dakwah menjadi implikasi dari ajaran Islam yang rasional. AlFaruqi menegaskan bahwa rasionalitas adalah salah satu watak dakwah Islam, artinya dakwah haruslah berdasarkan fakta bukan mitos, tidak bertentangan dengan nalar, terbuka pada bukti-bukti ilmiah baru, dan menghindari literalisme, fanatisme, dan konservatisme. ${ }^{23}$ Basit membahasakannya sebagai salah satu prinsip dakwah Islam, bahwa dakwah harus dilakukan dengan prinsip rasionalitas, yaitu secara objektif dan sesuai cara berpikir manusia. ${ }^{24}$ Dalam perspektif dakwah Qurani, Muhiddin menjelaskan bahwa sasaran utama dakwah adalah kesadaran pribadi, untuk itu pendekatan dan watak dari kegiatan dakwah harus melalui cara-cara pencerahan pemikiran, penyejukan jiwa tanpa harus menggunakan cara kekerasan dan kekuatan. ${ }^{25} \mathrm{Al}$-Warisyi dengan meneliti jalan dakwah tujuh rasul menyimpulkan bahwa dakwah Illahiah yang dilakukan para rasul

22 Matthew B. Miles \& Michael A. Huberman, Qualitative Data Analysis, A Sourccebook of New Methods, (London, Beverly Hills: Sage Publications, 1984).

${ }^{23}$ Ismail Raji Al-Faruqi dan Lois Lamya Al-Faruqi, Atlas Budaya Islam Menjelajah Khazanah Peradaban Gemilang, diterjemahkan Ilyas Hasan, (Bandung: Mizan, 1998), 220-221.

${ }^{24}$ Basit, Filsafat Dakwah, 61-62. senantiasa melewati pendekatan rasional, di antaranya dengan mengajak umatnya memikirkan kejadian alam dan manusia, mengoreksi sembahan-sembahan mereka, tidak jarang pula disertai kekuatan mukjizat. ${ }^{26}$ Aziz menyimpulkan bahwa sifat dasar dakwah Islam adalah rasionalitas. Rasionalitas tersebut dalam hal tujuan, pesan, metode, media, dan mitra dakwahnya yang menjadi sasaran, yaitu manusia sebagai makhluk yang berakal. Pendekatan rasional pernah berkembang pesat pada zaman klasik Islam, yang terbukti membawa kemajuan kebudayaan dan peradaban yang tinggi. Para ulama memiliki pemikiran yang terbuka, pandangan yang luas, dan sikapnya menjadi dinamis, sebab pendekatan rasional berkembang dengan baik. ${ }^{27}$ Berdasarkan pendapat para ahli di atas dapat disimpulkan bahwa dakwah Islam haruslah didekati secara rasional, dan hanya dengan cara itulah kebesaran ajaran Islam akan terlihat dan diakui masyarakat dunia.

Pendekatan rasional terkait erat dengan penggunaan logika atau ilmu penalaran sebagai dasar memahami dan memecahkan masalah. Logika melatih untuk menganalisis suatu jalan pikiran, menguji kesimpulankesimpulan yang ditarik, dan kepastian yang dapat dicapai, sehingga mampu membedakan pemikiran yang tepat, lurus, dan benar dari yang kacau serta salah. ${ }^{28}$ Dalam menghadapi permasalahan yang lebih kompleks, pendekatan rasional diimplementasikan dalam langkah-langkah

25 Asep Muhiddin, Dakwah dalam Perspektif Alquran, (Bandung: Pustaka Setia, 2002), 157.

${ }^{26}$ Al-Warisyi, Dakwah Illahiah., 118.

27 Harun Nasution, Islam Rasional: Gagasan dan Pemikiran, Editor Saiful Muzani, (Bandung: Mizan, 2000), 98

28 W. Poespoprodjo \& EK. T. Gilarso, Logika IImu Menalar, (Bandung: Pustaka Grafika, 1999), 12. 
pemecahan masalah yang dapat dipertanggungjawabkan, atau disebut metode ilmiah. Metode ilmiah merupakan ekspresi cara kerja pikiran (berpikir ilmiah), yang dengan itu diharapkan akan menghasilkan pengetahuan atau pemecahan masalah yang rasional (masuk akal), dan teruji. Untuk itu dapat digunakan cara-cara berpikir deduktif, dengan berpangkal pada pengetahuanpengetahuan terkait sebelumnya, maupun berpikir induktif, dengan berpangkal pada fakta-fakta empiris. ${ }^{29}$

Pendekatan rasional dalam dakwah berarti penggunaan cara berpikir ilmiah, baik secara deduksi maupun induksi, untuk memahami dan memecahkan masalah dakwah. Dakwah sebagai fenomena sosial dapat diamati, diteliti, dan dikembangkan menjadi sebuah ilmu pengetahuan (sains) dakwah, yang oleh beberapa ahli digolongkan sebagai sains sosial. ${ }^{30}$ Selain ilmu-ilmu Keislaman seperti tafsir, studi hadis, ushul fikih, dan sejenisnya, ilmu-ilmu sosial lainnya dapat menjadi alat bantu dalam pengembangan keilmuan dan kegiatan dakwah. Ilmu-ilmu sosial tersebut seperti sosiologi, antropologi, komunikasi, psikologi, pemasaran, ekonomi, politik, manajemen, pendidikan, dan lain-lain. ${ }^{31}$ Pendekatan rasional dalam dakwah berarti juga penggunaan ilmu-ilmu terkait sebagai alat bantu untuk memahami dan memecahkan problematika dakwah yang semakin kompleks di masyarakat modern. Maka pemahaman terhadap pesan dan metode

29 Jujun S. Suriasumantri, Filsafat IImu: Sebuah Pengantar Populer, (Jakarta: Sinar Agape Press, 1985), 119-120.

30 Beberapa ahli tersebut adalah: Cik Hasan Bisri, Imam Sayuti Farid, dan Sukriadi Sambas, dan Ali Aziz. Lihat: Aziz., Ilmu Dakwah., 60.

31 Ibid., 71. dakwah yang rasional perlu memiliki basis keilmuan, baik yang bersumber dari keilmuan Islam maupun sains sosial.

\section{Pesan dan Metode Dakwah}

\section{Rasionalitas Pesan Dakwah Islam}

Fenomena komunikasi dengan fenomena dakwah memiliki banyak kesamaan meskipun juga ada perbedaannya. Dalam konteks komunikasi, pesan adalah apa yang dikomunikasikan oleh sumber (komunikator) kepada penerima (komunikan). Pesan merupakan seperangkat simbol verbal atau nonverbal yang mewakili perasaan, nilai, gagasan, dan maksud komunikator. Pesan memiliki tiga komponen, yaitu: (a) makna; (b) simbol, yang digunakan menyampaikan makna; dan (c) bentuk atau organisasi pesan. Pesan dalam komunikasi dakwah adalah yang disampaikan dai kepada mad'uw. $^{32}$ Jika komunikasi mencakup semua jenis pesan, maka dakwah dengan karakteristik yang dimilikinya lebih fokus kepada pesan yang berisi seruan al-khayr, amar makruf, dan nahi mungkar, serta tentang ajaran Islam yang bersumber terutama dari Alquran dan hadis, dan dilakukan oleh orang Islam sebagai dai atau mubalig kepada seseorang atau khalayak. ${ }^{33}$ Pesan dakwah tidak hanya mengandung kata-kata saja, tetapi juga mengandung makna dan dimensi penerimaan pesan dakwah oleh mitra dakwah, juga tidak hanya bersifat verbal melainkan juga nonverbal. ${ }^{34}$ Sejalan dengan karakter Islam sebagai agama fitrah,

32 Wahyu Ilaihi, Komunikasi Dakwah (Bandung: PT. Remaja Rosdakarya, cetakan pertama, 2010), 97

${ }^{33}$ Anwar Arifin, Dakwah Kontemporer, Sebuah Studi Komunikasi (Yogyakarta: Graha IImu, Cetakan ke-1, 2011), 39.

${ }^{34}$ Basit., Filsafat Daklwah., 142. 
rasional, dan universal, maka pesan dakwah juga memiliki karakter sesuai dengan fitrah, rasional, dan universal.

Pesan dakwah sebagai materi haruslah mengandung nilai-nilai dan prinsip-prinsip dasar sebagai petunjuk umat manusia untuk mencapai kesejahteraan dunia akhirat yang tersampul dalam praktik pengesaan Allah Swt sebagai sumber dari segala sumber, dan tidak menyekutukan-Nya dalam berbagai zat, sifat maupun perbuatan-Nya. ${ }^{35}$ Penelusuran terhadap jalan dakwah tujuh rasul yang dilakukan oleh Al-Warisyi juga menyimpulkan bahwa tiap-tiap rasul diperintahkan untuk menyampaikan konsep ketauhidan kepada masyarakat jahiliyah, yaitu memberitahukan bahwa tidak ada Rabb dan ilah melainkan Allah, dengan senantiasa melewati pendekatan rasional. ${ }^{36}$ Dengan demikian, ajaran tauhid menjadi inti atau dasar dari pesan dakwah Islam. Tauhid tidak hanya diartikan sebagai kepercayaan terhadap keesaan Tuhan, melainkan mencakup pengertian bahwa segala sesuatu harus selalu dikaitkan dengan keesaan-Nya sebagai sumber segala sumber. Keyakinan ini antara lain mengantarkan manusia kepada kesatuan sebagai bentuk tunggal, sehingga tidak terjadi pemisahan antara dunia dan akhirat atau jiwa dan raga, alamiah dan supraalamiah serta hal lain yang serupa dengannya. ${ }^{37}$ Ajaran Islam sebagai materi dakwah dapat dikembangkan dan diklasifikasikan menjadi: (a) pesan akidah; (2) pesan syariah, baik ibadah maupun muamalat; dan (c) pesan akhlak. ${ }^{38}$ Sementara Ali Yafie menyebut pesan

\footnotetext{
35 Aswadi, Dakwah Progresif Perspektif Allquran, (Sidoarjo: Dwiputa Pustaka Jaya, 2016), 125.

${ }^{36}$ Ketujuh rasul tersebut adalah: Nuh, Hud, Shalih, Ibrahim, Syuaib, Musa, dan Muhammad. Lihat: AlWarisyi., Dakwah Illahiah, 118.
}

dakwah itu ada lima pokok meliputi: (a) masalah kehidupan; (b) masalah manusia; (c) masalah harta benda; (d) masalah ilmu pengetahuan; dan (e) masalah akhlak. ${ }^{39}$ Dalam perspektif dakwah sebagai sebuah sistem, pesan dakwah perlu diproses dan dimanajemen sedemikian rupa agar dapat menjawab problematika yang dihadapi masyarakat yang menjadi mitra dakwah. Sehingga ajaran Islam yang disajikan menjadi pesan dakwah bisa dirasakan secara riil manfaatnya oleh masyarakat. Dalam penyajian pesan dakwah juga perlu disesuaikan dengan karakteristik masyarakat yang menjadi mitra dakwah, situasi lingkungan yang dihadapi, ketersediaan subjek atau sumber daya manusia pelaksana dakwah, ketersediaan media, peralatan, dan sebagainya.

Dengan demikian dimensi-dimensi rasionalitas pesan dakwah adalah: (a) sejalan dengan ajaran Islam yang rasional, yang berarti juga sesuai fitrah dan universal; (b) inti pesannya adalah ajaran ketauhidan, yang mengandung nilai-nilai kebaikan (alkhayr). Pesan tersebut dapat dikembangkan ke dalam tema-tema besar meliputi akidah, syariah, dan akhlak, yang perlu dipahami secara rasional pula; (c) sumber pesan dakwah secara garis besarnya adalah Alquran, hadis, dan ilmu pengetahuan (hasil akal/ijtihad); (d) penyajian pesan dakwah idealnya mampu menjawab problematika masyarakat yang dihadapi; (e) penyajian pesan dakwah juga perlu disesuaikan dengan karakter masyarakat yang menjadi mitra dakwah.

\footnotetext{
${ }^{37}$ M. Quraish Shihab, Membumukan Al-Quran: Fungsi dan Peran Wahyu Dalam Kehidupan Masyarakat, (Bandung: Mizan, 1995), 301.

38 Ilaihi, Komunikasi Dakwah, 101-102.

$39 \mathrm{lbid}, 102-103$.
} 


\section{Rasionalitas Metode Dakwah Islam}

Metode dakwah adalah cara-cara tertentu yang dilakukan oleh seorang dai (komunikator) kepada mad'uw untuk mencapai suatu tujuan atas dasar hikmah dan kasih sayang. ${ }^{40}$ Metode dakwah harus mampu melakukan perbaikan pemahaman, cara berpikir, sikap, dan tindakan (aktivitas) dari pemahaman yang sempit, dan kaku, berubah menjadi positif dan berwawasan luas; dari sikap menolak, ragu-ragu, berubah menjadi sikap menerima (iman) dengan jalan ilm al-yakin, haqqu al-yakin, dan alainu al-yakin, ${ }^{41}$ yang dalam arti lain keimanan yang didasari pengetahuan ilmiah baik secara rasional maupun empiris yang dapat dipertanggungjawabkan. Apabila memperhatikan isyarat ayat-ayat yang khusus berkaitan dengan metode komunikasi, tampak bahwa Alquran seringkali menyampaikan ungkapannya secara ilustratif melalui penyataan dengan cara yang baik, sopan, lemah-lembut, dan kadang dengan penyataan yang berbobot, berbekas, tegas dalam proses komunikasi dialogis dan kondusif, yang mampu menyejukkan jiwa sekaligus membangkitkan daya nalar sesuai dengan kontekstualisasi mad'uw. $^{42}$

Rasionalitas metode dakwah Islam dapat dilihat sebagaimana Alquran dalam menyajikan materi dakwahnya. Alquran terlebih dahulu meletakkan prinsip bahwa manusia (mad'u) adalah makhluk yang memiliki unsur jasmani, akal, dan unsur kejiwaan lainnya, sehingga harus dilihat dan diperlakukan secara integral dan

\footnotetext{
40 Mundzir Suparta dan Harjani Hefni (ed), Metode Dakwah (Jakarta: Prenada Media. Cet-1, 2003), 7-8.

${ }^{41}$ Asep Muhyiddin dan Agus Ahmad Syafei, Metode Pengembangan Dakwah (Bandung: CV. Pustaka Setia. Cet. 1, 2002)., 71.
}

komprehensif, serentak dan simultan, baik dari segi materi maupun waktu dan penyajiannya. Menurut Shihab, materi dakwah yang disajikan Alquran dalam membuktikan kebenaran adalah dengan metode yang argumentatif dan dapat dibuktikan manusia dengan menggunakan penalaran akalnya. Kenyataan ini hampir dijumpai di dalam semua permasalahan yang disajikan Alquran. Adakalanya Alquran menuntun manusia dengan redaksi-redaksi yang sangat jelas dan dengan tahapan pemikiran yang sistematis sehingga manusia menemukan sendiri kebenaran yang dikehendakinya. ${ }^{43}$

Prinsip-prinsip metode dakwah Qurani secara umum dilandaskan pada surah Annahl ayat 125, yang menyatakan: "Serulah (manusia) kepada jalan Tuhan-mu dengan hikmah dan pelajaran yang baik dan bantahlah mereka dengan cara yang baik. Sesungguhnya Tuhanmu Dialah yang lebih mengetahui tentang siapa yang tersesat dari jalan-Nya dan Dialah yang lebih mengetahui orang-orang yang mendapat petunjuk." Berdasarkan ayat tersebut, maka hakikat metode dakwah adalah aktifitas mengajak manusia ke jalan Tuhan (Islam) dengan menggunakan metode (cara) hikmah (bil-hikmah) atau kebijaksanaan, nasehat dengan cara yang baik (mau'idhah al-hasanah), berdebat dengan yang baik (wajaadilhum billati hiya ahsan).

Metode dakwah yang rasional perlu memperhatikan batasan atau etika dalam berdakwah. Al-Warisyi menjelaskan bahwa

\footnotetext{
42 Ibid., 74.

43 Ibid., 75-76.
} 
etis jalan dakwah para rasul dalam menyampaikan ketauhidan adalah tidak dengan segala cara, melainkan pelakunya (rasul dan pengikutnya) memercayai kebenaran konsep tauhid dan melaksanakannya pada kehidupan masyarakat, tidak boleh mengikuti jalan hidup orang-orang musyrik, kafir, dan yang mengikuti hawa nafsunya. Selain itu dakwah bersifat sekadar menyampaikan amanat, tidak memaksa, dengan tujuan agar mitra dakwah dapat memperbaiki kekeliruannya dan mengikuti jalan yang benar. ${ }^{44}$ Suparta dan kawan-kawan, merinci beberapa rambu etis yang tidak boleh dilakukan dalam berdakwah, yaitu: (a) tidak memisahkan antara ucapan dan perbuatan; (b) tidak melakukan toleransi dalam agama (keimanan); (c) tidak menghina sesembahan nonmuslim; (d) tidak melakukan diskriminasi sosial; (e) tidak berteman dengan pelaku maksiat; (f) tidak menyampaikan hal-hal yang tidak diketahui. ${ }^{45}$ Basit juga merinci beberapa etika dakwah, yaitu: (a) dakwah hendaknya dilakukan dengan menafikan unsur-unsur kebencian, esensi dakwah mesti melibatkan dialog bermakna yang penuh kebijaksanaan, perhatian, kesabaran, dan kasih sayang; (b) dakwah hendaknya dilakukan secara persuasif, jauh dari sikap memaksa; (c) menghindari pikiran dan sikap menghina dan menjelek-jelekkan agama atau Tuhan yang menjadi keyakinan umat lain; (d) mengapresiasi perbedaan dan menjauhi sikap ekstremisme dalam beragama; (e) dakwah hendaknya dilakukan jujur dan proporsional. ${ }^{46}$
Sebagai bagian dari sistem dakwah, maka metode dakwah harus bersifat dinamis dan kontekstual sesuai dengan objek yang dihadapi. Kekuatan pilihan suatu metode sangat dipengaruhi faktor-faktor eksternal di luar metode, seperti materi atau pesan dakwah yang hendak disajikan, dan khususnya kepada siapa dakwah itu dilakukan (mitra dakwah). ${ }^{47}$ Pada intinya pilihan metode dakwah sangat beragam. Agar metode dakwah yang dipilih dapat efisien dan efektif, setidaknya, para subjek dakwah harus mengetahui metode yang tepat untuk digunakan, waktu penggunaan, dan keefektifan dalam mempergunakan masing-masing metode. Dalam arti sebelum menentukan pilihan metode perlu dilakukan penyelidikan terlebih dahulu terhadap variabel terkait dan dipandang dapat menghasilkan sesuatu yang diinginkan. ${ }^{48}$

Dengan demikian rasionalitas metode dakwah mengandung dimensi-dimensi: (a) secara umum dilaksanakan dengan cara hikmah, nasehat yang baik, dan dialog/diskusi dengan baik; (b) tidak dilakukan dengan segala cara, melainkan sejalan dengan etika dakwah, yang antara lain tidak memaksa, tidak menghina, sekadar menyampaikan dan persuasif, jujur dan tidak menyampaikan yang tidak diketahui; (d) menyesuaikan karakter mitra dakwah; (e) memperhatikan variabelvariabel lainnya seperti pesan/materi dakwah, media, subjek, dan sebagainya.

\footnotetext{
47 A. Ilyas Ismail dan Prio Hotman, Filsafat Dakwah: Rekayasa Membangun Agama dan Peradaban Islam, (Jakarta: Kencana, 2011), 200.

48 Muhiddin., Dakwah dalam., 173.
}

${ }^{44}$ Al-Warisyi, Dakwah Illahiah., 118-119.

${ }^{45}$ Suparta \& Hefni., Metode Dakwah., 83-92.

${ }^{46}$ Basit, Filsafat Dakwah, 212-218. 


\section{Masyarakat Modern Kontemporer Indonesia sebagai Mitra Dakwah}

Dalam kaitannya dengan mitra dakwah, rasionalitas pesan dakwah mengasumsikan bahwa pesan dakwah idealnya mampu menjawab problematika sosial yang dihadapi mitra dakwah. Dakwah sebagai salah satu sistem sosial diharapkan menjadi penyembuh kerusakan (patologi) yang ada di masyarakat. Dalam rasionalitas metode dakwah, juga perlu memperhatikan karakter dari masyarakat yang menjadi mitra dakwah. Menjadikan masyarakat modern sebagai mitra dakwah, maka setidaknya perlu diuraikan tiga hal, yaitu: (1) konsepsi masyarakat modern kontemporer; (2) karakteristik masyarakat modern kontemporer, khususnya dalam konteks Indonesia; dan (3) problematika masyarakat modern kontemporer, dalam konteks Indonesia. Ketiganya menjadi pijakan dalam analisis pesan dan metode dakwah berbasis rasional pada masyarakat modern.

\section{Konsepsi Masyarakat Modern Kontemporer}

Dari sisi sosiohistoris, masyarakat modern umumnya merujuk pada masyarakat Eropa (Barat). Modernisme ala Barat tersebut sebagaimana dijelaskan Toynbe, telah dimulai sejak menjelang akhir abad kelima belas masehi, yaitu ketika orang Barat berterimakasih tidak kepada Tuhan, tetapi kepada dirinya sendiri karena ia telah berhasil mengatasi kungkungan Kristen abad pertengahan. Kekuatan untuk keluar dari doktrin gereja telah menggeser cara pandang masyarakat gereja untuk berpikir rasional dan modern. ${ }^{49}$ Sehingga menjadi

\footnotetext{
49 Nurcholish Madjid, Islam Doktrin dan Peradaban, Sebuah Telaah Kritis tentang Masalah Keimanan, Kemanusiaan dan Kemodernan (Jakarta: Paramadina, 2000), 450.

50 Ibid., 451-452.
}

suatu hal yang lazim apabila di masyarakat modern Barat, agama ditinggalkan, atau sekurang-kurangnya dipandang sebagai suatu ranah privat. Dari sudut hakikatnya sebenarnya zaman modern bersifat netral saja. ${ }^{50}$

Senada dengan pandangan Hodgson dalam bukunya The Venture of Is/am, ${ }^{51}$ Madjid lebih suka menyebut zaman modern dengan "Zaman Teknik" (Technical Age) yaitu adanya peran sentral teknikalisme dan bentuk-bentuk masyarakat yang terkait dengan teknikalisme itu, yang didorong oleh adanya Revolusi Industri (teknologis) di Inggris (1776) dan Revolusi Sosial-Politik di Perancis (1789). Dampaknya masyarakat tidak hanya dihadapkan dengan masalah kulturalnya sendiri secara terpisah dan otonom, akan tetapi didorong menuju masyarakat jagad (global). ${ }^{52}$ Sehingga masyarakat modern pada hakikatnya adalah masyarakat teknik, yaitu masyarakat yang melakukan teknikalisasi pada berbagai bidang dengan tuntutan efisiensi kerja yang tinggi.

Secara filosofis dapat dipahami bahwa teknikalisasi dalam bidang industri dan berbagai bidang lainnya terjadi karena adanya sikap dan pola pikir masyarakatnya, yang ketika itu terjadi di Barat. Mereka membebaskan diri dari tahayul dan mistis, dan beralih pada pola pikir rasional. Mereka mengadakan berbagai penyelidikan ilmiah dan menghasilkan ilmu pengetahuan, yang diaplikasikan dalam bentuk teknologi. Maka modernisasi terkait proses perubahan sikap

\footnotetext{
${ }^{51}$ Marshal G.S. Hodgson, The Venture of Islam: Iman dan Sejarah dalam Peradaban Dunia Masa Klasik. Buku Pertama: Lahirnya Sebuah Tatanan Baru, (Jakarta: Paramadina, 1999).

52 Madjid, Islam Doktrin., 452.
} 
dan pola pikir yang sesuai dengan tuntutan zaman. Madjid menyebutnya sebagai proses perombakan pola berpikir dan tata kerja lama yang tidak rasional dan menggantinya dengan pola berpikir dan tata kerja baru yang rasional, yang dilakukan dengan menggunakan penemuan mutakhir manusia di bidang ilmu pengetahuan. ${ }^{53}$

Sebagaimana yang disampaikan Schrool, bahwa modernisasi merupakan penerapan pengetahuan ilmiah pada semua kegiatan, bidang kehidupan dan aspek kemasyarakatan. Aspek yang paling menonjol dalam proses modernisasi adalah perubahan ilmu pengetahuan dan teknologi yang tinggi. Maka masyarakat modern adalah masyarakat yang memiliki sikap dan cara berpikir yang rasional dan menerapkan pengetahuan ilmiah pada keseluruhan sektor masyarakatnya. Dimensi kontemporer masyarakat modern merujuk pada era globalisasi saat ini, sebagai akibat dari perkembangan teknologi informasi dan komunikasi (TIK) yang telah menjadi penopang bagi berbagai aktivitas masyarakat modern. Perkembangan yang begitu pesat tersebut telah mengubah banyak hal di dunia. Terciptalah apa yang disebut sebagai dunia maya. Kecanggihan teknologi informasi dan komunikasi tersebut telah banyak dimanfaatkan masyarakat modern dalam berbagai hal, termasuk pengajaran agama.

\section{Karakteristik Masyarakat Modern Indonesia Kontemporer}

Inti penggerak dari masyarakat modern adalah pada derajat rasionalitasnya yang

53 Nurcholish Madjid, Islam Kemodernan, dan Keindonesiaan (Bandung: Mizan, 1997), 172.

${ }^{54}$ Ginandjar Kartasasmita, "Karakteristik dan Struktur Masyarakat Indonesia Modern" Sarasehan Uji Sahih menghasilkan dan menyandarkan pada ilmu pengetahuan dan teknologi dalam berbagai bidang. Kartasasmita menggambarkan beberapa ciri umum masyarakat modern yang rasional tersebut, yaitu: (a) dalam tindakan-tindakan sosial masyarakat modern. Tindakan-tindakan sosial masyarakat modern lebih banyak bersifat pilihan, oleh karenanya ciri terpenting masyarakat modern adalah kemampuan dan hak masyarakat untuk mengembangkan pilihan-pilihan dan mengambil tindakan berdasarkan pilihan tersebut; (b) orientasi terhadap perubahan, masyarakat modern senantiasa berubah cepat, bahkan perubahan itu sendiri telah terlembaga; (c) berkembangnya organisasi dan diferensiasi, yang cakupannya makin luas dan makin rumit. $^{54}$

Menurut Inkeles, setidaknya terdapat sembilan ciri manusia modern yaitu: (a) memiliki sikap hidup untuk menerima halhal baru dan terbuka untuk perubahan; (b) memiliki keberanian untuk menyatakan pendapat atau opini mengenai lingkungannya sendiri atau kejadian yang terjadi jauh di luar lingkungannya serta dapat bersikap demokratis; (c) menghargai waktu dan lebih banyak berorientasi ke masa depan dari pada masa lalu; (d) memiliki perencanaan dan pengorganisasian; (e) percaya diri; (f) perhitungan; (g) menghargai harkat hidup manusia lain; (h) percaya pada ilmu pengetahuan dan teknologi; (i) menjunjung tinggi suatu sikap di mana imbalan yang diterima seseorang harus sesuai dengan prestasinya dalam masyarakat. ${ }^{55}$

atas Pokok-pokok Pikiran tentang GBHN 1998. Yogyakarta, 29 Juni 1997.

${ }^{55}$ Alex Inkeles and David H. Smith, Becoming Modern (Cambridge: Harvard Universit Press,1 974). 
Ciri-ciri tersebut tentu masih belum cukup memadai untuk memahami karakteristik masyarakat Indonesia modern. Karakteristik menonjol dari Indonesia sebagai bangsa adalah kebesaran, keluasan dan kemajemukannya. Indonesia memiliki lebih dari 1.128 suku bangsa dan bahasa, dengan beragam agama dan budaya yang mendiami sekitar 17.508 pulau. ${ }^{56}$ Suatu hal yang tidak dapat diingkari bahwa Indonesia memiliki keragaman budaya. Perbedaan-perbedaan tersebut diikat dalam satu konsepsi pokok yaitu prinsip gotong royong, bahwa negara ini adalah negara bersama, yang dimiliki dan dibangun bersama-sama. Prinsip tersebut tertulis dalam konstitusi dasar Indonesia, sehingga wawasan persatuan dan kebinekaan adalah hal penting agar bisa menerima dan memberi ruang bagi adanya perbedaan. ${ }^{57}$ Kemajemukan dan keluasan wilayah Indonesia menjadikan masyarakatnya sangat beragam dalam penerimaannya terhadap modernisasi. Sampai dengan hari ini masih terdapat sukusuku di pedalaman Indonesia yang menolak modernisasi. Sebagian masyarakat ada yang mencomot sepenuhnya gaya hidup ala masyarakat Barat, ada yang menerima sebagian dan menolak sebagian, ada yang memilah-milahnya, dan sebagainya.

Dalam konteks Indonesia, fenomena masyarakat modern banyak dijumpai pada masyarakat perkotaan. Sekalipun tidak semua orang kota memiliki sikap dan cara berpikir yang modern. Aripudin menggambarkan karakteristik masyarakat perkotaan sebagai berikut: (a) dalam usaha pencarian hidup, masyarakat kota banyak menggunakan fasilitas-fasilitas lebih modern; (b) sistem kemasyarakatannya tertata jelas, sehingga setiap anggota

56 Pimpinan MPR dan Tim Kerja Sosialisasi MPR Periode 2009-2014, Empat Pilar Kehidupan Berbangsa dan Bernegara, (Jakarta: Sekretariat Jendral MPR RI, 2012), 1. masyarakat memiliki status sesuai profesinya; (c) dalam berkomunikasi, umumnya masyarakat kota memakai bahasa yang lebih menasional; (d) sistem pengetahuan pada masyarakat kota lebih cenderung pragmatis; (e) masyarakat kota umumnya sangat heterogen. ${ }^{58}$ Sebagai mitra dakwah maka ciri umum masyarakat modern dan karakteristik budaya masyarakat perkotaan di Indonesia dapat menjadi pijakan dalam penyajian pesan dan metode dakwah berbasis rasional.

\section{Problematika Masyarakat Modern Indonesia Kontemporer}

Rasionalitas pesan dakwah mengasumsikan bahwa pesan dakwah haruslah mampu menjawab problematika masyarakat yang menjadi mitra dakwah. Dalam arti isi dakwah harus memiliki basis riil masyarakat mitra dakwah, sehingga dakwah Islam tidak menjadi suatu yang normatif, tetapi mampu dirasakan kebermaknaannya dalam kehidupan nyata. Problematika masyarakat modern dapat dipahami dari dampak sosial yang dihasilkan. Masyarakat modern sebagaimana aspek sosiohistorisnya tidak hanya menghasilkan dampak positif berupa kemajuan dan kemudahan, namun juga dampak-dampak negatif sebagai akibat dari ditinggalkannya dimensi spiritual dalam masyarakat.

Hingar bingar teknologi dan kecepatan arus informasi global telah banyak memengaruhi kehidupan manusia modern, yang senantiasa memandang persoalan hidup secara pragmatis, serba instan, dan cenderung matematis. Naisbiit menuturkan bahwa kemajuan teknologi yang

\footnotetext{
57 MPR., Empat Pilar., 2, 5-6.

${ }^{58}$ Acep Aripudin, Sosiologi Dakwah, (Bandung: Rosda, 2013), 52-54.
} 
berkembang telah membuat manusia modern menjadi gamang. ${ }^{59}$ Bagaimana tidak gamang jika dimensi kerohanian manusia diabaikan, sementara teknologi, kebebasan, dan materi dipuja sedemikian rupa. Basit menjelaskan bahwa dampak negatif dari peradaban modern yang sekarang terjadi adalah munculnya sikap materialisme, konsumerisme, dan hedonisme di kalangan masyarakat, munculnya berbagai patologi sosial, dan terjadinya anomali atau keterasingan manusia, baik terhadap dirinya, lingkungannya, dan Tuhannya. ${ }^{60}$

Dalam konteks Indonesia, modernisasi yang dilakukan sedikit banyak mengacu pada masyarakat modern ala Barat. Sehingga dampak-dampak negatif sebagaimana di atas tampaknya telah menggejala di masyarakat Indonesia sekarang ini, karena Indonesia telah memasuki kehidupan modern seperti negara-negara lain. Dampak negatif tersebut diperparah dengan keadaan masyarakat Indonesia yang belum sepenuhnya siap secara mental dalam menghadapi kehidupan modern. Kenyataannya masih banyak rakyat Indonesia yang tingkat pendidikan dan literasinya rendah. Akibatnya masyarakat Indonesia belum maksimal memanfaatkan kemajuan ilmu pengetahuan dan teknologi untuk kemajuan masyarakat, sebaliknya banyak masyarakat yang terbawa arus dengan mengikuti kecenderungankecenderungan negatif kehidupan modern. ${ }^{61}$

\footnotetext{
59 John Naisbitt, High Tech, High Touch: Technology and Our Search for Meaning (New York: Broadway, 1999).

${ }^{60}$ Abdul Basit, Wacana Dakwah Kontemporer. Editor: Abdul Wachid, (Yogyakarta: STAIN Purwokerto \& Pustaka Pelajar, 2005), 61.

61 lbid., 62.
}

Kelas menengah masyarakat kota menjadi salah satu yang terpapar dampak-dampak negatif modernisme ala Barat. Keresahan tersebut ditimbulkan karena adanya pola kehidupan mekanik yang serba statis telah menciptakan adanya pendisplinan tubuh bagi kaum modernis. ${ }^{62}$ Akibatnya, penduduk kelas menengah perkotaan tidak memiliki ruang ekspresi lebar dalam mengartikulasikan keinginannya. Keresahan kehidupan tersebut ditandai dengan perasaan teralienasi (terasing) dan maraknya peristiwa bunuh diri. Keterasingan yang dialami kelas menengah masyarakat modern kemudian memunculkan berbagai macam ekspresi religiusitas yang ditampilkan oleh penduduk perkotaan tersebut selain halnya dimaknai sebagai bentuk peningkatan religiusitas, juga dapat dimaknai sebagai bentuk era rekonstruksi agama, atau lebih tepatnya gerakan agama/zaman baru (new age movement). ${ }^{63}$

Dengan demikian dapat disimpulkan bahwa masyarakat Indonesia modern kontemporer juga tengah mengalami gejala-gejala negatif modernisme yang ditimbulkan oleh Barat. Sekalipun tidak keseluruhan masyarakat Indonesia menerima atau menerapkan modernitas, tetapi gejala-gejala masalahnya dapat diamati, khususnya yang terjadi di kota-kota besar. Sehingga tidak mengherankan jika di perkotaan yang menjadi basis masyarakat modern, patologi sosial dengan beraneka bentuk, seperti kenakalan remaja, pelacuran dan seks

62 Muhammad Anis, "Spiritualitas di Tengah Modernitas Perkotaan", Jurnal Bayan, Volume. 2, No. 4, (2013) 1-15

63 Wasisto Raharjo Jati, "Sufisme Urban: Konstruksi Keimanan Baru Kelas Menengah Muslim" Jurnal Kajian dan Pengembangan Manajemen Dakwah, Vol 5 no 2 Des 2015, 176. 
bebas, narkoba, kekerasan sosial, alienasi, bunuh diri, dan sebagainya, masih marak terjadi. Belum lagi masalah kesenjangan ekonomi, perilaku politik segala cara, oknum birokrat yang koruptif, dan lain-lain. Gerakan agama baru yang menjadi pelarian masyarakat modern belum sepenuhnya menjawab atau menyelesaikan persoalan tersebut. Dakwah sebagai sistem penyembuh masalah masyarakat, diharapkan dapat dilaksanakan berbasis problematika kontemporer tersebut.

\section{Penyajian Pesan dan Metode Dakwah Berbasis Rasional pada Masyarakat Modern}

Menurut watak dan dinamikanya sendiri sebenarnya modernitas adalah budaya dunia, akan tetapi dalam berbagai kenyataan periferalnya, ia membawa juga berbagai sisa limpahan (carry on) budaya Barat. $^{64}$ Masyarakat modern Indonesia adalah masyarakat modern tidak hanya menghasilkan dampak positif berupa kemajuan dan kemudahan, namun juga dampak-dampak negatif sebagai akibat dari ditinggalkannya dimensi spiritual dalam masyarakat. Oleh karena itu diperlukan dakwah yang mampu memberikan pesan dakwah dan metode yang relevan dengan problematika masyarakat modern, sekaligus mampu memberikan solusi atas problematika tersebut.

\section{Pesan Dakwah}

Pesan dakwah pada hakikatnya mengandung aspek-aspek yang sangat terikat konteks ruang dan waktu karena realitas masyarakat secara sosiologis dan historis senantiasa mengalami perubahan dan perkembangan. Meskipun demikian pada hal-hal yang bersifat prinsip yaitu esensi kebaikan atau kebenaran ajaran Islam tetap harus disampaikan sesuai konteks ruang dan waktu. Dengan kata lain, perlu diperhatikan cara menarik esensi kebenaran pesan dakwah Islam dalam konteks ruang dan waktu yang pasti mengalami perubahan dan perkembangan. $\mathrm{Di}$ sinilah letak rasionalitas pesan dakwah Islam yang harus dipahami oleh para dai.

Esensi pesan dakwah Islam yang berbasis rasional adalah bagaimana mengaitkan antara pesan-pesan dakwah tersebut dengan problematika realitas masyarakat modern, yang sudah barang tentu berbeda secara sosiologis dan historis dengan konteks masyarakat Islam abad klasik atau abad pertengahan. Sehingga mendasarkan pesan-pesan dakwah bagi masyarakat modern dengan menggunakan acuan (reference) taken for granted isi kandungan dan penjelasannya sebagaimana yang terjadi pada masa masyarakat abad klasik dan pertengahan adalah pengacuan masalah yang tidak bijaksana, dan pada akhirnya tidak memberikan solusi bagi masyarakat modern. Sebab salah satu ciri manusia modern adalah sangat berorientasi pada masa depan daripada masa lalu. Selain itu manusia modern memiliki sikap hidup untuk menerima hal-hal baru dan terbuka untuk perubahan.

Pesan dakwah sangat terkait dengan materi dakwah (maddah) yang khas, karena tidak lain adalah nilai-nilai kebaikan (al-khayr), amar makruf dan nahi mungkar. Materi dakwah juga sangat luas dan dalam, karena

${ }^{64}$ Madjid, Islam Doktrin., 453. 
pada hakikatnya menyangkut seluruh ajaran Islam baik yang terdapat ayat-ayat Allah yang tertulis (qauliyah) maupun yang tidak tertulis (qauniyah) yang terjabar di alam semesta, yang pada intinya terkait dengan masalah Tuhan, Manusia dan Alam (TMA). Akan tetapi fenomena yang terjadi saat ini, materi dakwah cenderung berkutat pada masalah-masalah syariah, seperti materi fikih, muamalah, dan akhlak, yang mana dalam pembahasan masalah tersebut kecenderungan pendekatannya tekstual dan kebahasaan semata. Padahal sebagaimana dideskripsikan di atas bahwa manusia pada masyarakat modern punya sikap keterbukaan kepada perubahan dan sangat menghargai ilmu pengetahuan dan teknologi yang dapat dimanfaatkan untuk menyampaikan pesan dakwah, seperti penggunaan berbagai disiplin ilmu pengetahuan terkait untuk menjelaskan ajaran-ajaran Alquran dan hadis sesuai dengan materi dakwah, apakah terkait dengan aspek ketuhanan, kemanusiaan, atau kealaman, baik dengan menggunakan ilmu-ilmu sosial, ilmu-ilmu eksakta ataupun ilmu humaniora. Sehingga kecenderungan penggunaan pendekatan kebahasaan saja secara eksesif dapat diperkaya dengan berbagai disiplin ilmu pengetahuan tersebut dan dapat memperluas cakrawala pemahaman mengenai ajaran-ajaran Islam. Pada prinsipnya diperlukan penyajian pesan dakwah dengan pendekatan ilmu pengetahuan terkait sesuai dengan variabel permasalahan dalam isi pesan dakwah yang diberikan oleh para dai. Oleh karenanya pesan dakwah kepada masyarakat modern perlu disajikan secara sistematis dan terkurikulum agar sejalan dengan karakter manusia modern dan mampu menjawab problematika masyarakat.
Kompleksitas masalah dalam masyarakat modern tidak mungkin dapat diselesaikan hanya dengan menyajikan materi dakwah yang bersifat spontanitas dan parsial. Sebagaimana banyak ditemui dalam berbagai kegiatan dakwah di masyarakat yang menyajikan materi dakwah dengan mengikuti momentum, seperti peringatan Isra Mikraj, maulid Nabi Muhammad, dan sebagainya, atau menyajikan materi dakwah dengan tema yang sedang marak (trending) dibahas di masyarakat. Materi dakwah juga tidak bisa hanya menekankan salah satu atau beberapa aspek dalam ajaran Islam, seperti soal fikih, membaca Alquran, dan lain-lain. Pembahasan yang demikian tentu tidak akan mampu menjawab problematika masyarakat modern. Untuk itu perlu dilakukan suatu analisis mendalam terkait problematika tersebut, dari situ dapat menjadi pijakan untuk mengembangkan materi-materi dakwah yang sistematis dan terkurikulum.

Dalam konteks masyarakat modern Indonesia, saat ini tengah mengalami berbagai problematika sosial sebagai ekses dari pola modernisme yang cenderung mengacu pada masyarakat Barat. Sekalipun masyarakat Indonesia memiliki watak religius, sebagaimana tercermin dalam sila pertama Pancasila, namun gelombang modernisme ala Barat yang menghantam keras melalui globalisasi telah menjadikan masyarakat modern Indonesia seperti kehilangan religiusitasnya (kepercayaan terhadap Tuhan). Materialisme, hedonisme, dan liberalisme menjadi gejala umum di masyarakat perkotaan besar Indonesia dengan berbagai bentuknya. Percaya pada Tuhan tetapi tidak melaksanakan ajaran-Nya dengan sungguh-sungguh. Hal tersebut karena kepercayaan terhadap Tuhan 
sekadar menjadi tradisi dan mengikuti kebiasaan pada keluarga atau masyarakat pada umumnya. Agama (Islam) dipandang sebagai keyakinan dan masalah privat, sehingga yang terjadi adalah sekularisasi kehidupan agama dan dunia. Disini terlihat ada persoalan terkait pengajaran ketauhidan. Ketauhidan yang menjadi inti pesan dakwah tidak disajikan melalui pendekatan rasional dan ilmu pengetahuan terkait. Akibatnya kepercayaan terhadap Tuhan yang dibangun sangat rapuh karena tidak dilandasi ilmu pengetahuan. Menghadapi serangan pemikiran masyarakat Barat yang cenderung ateis (tidak percaya Tuhan) akan kesulitan, bahkan malah terpengaruh. Oleh karenanya pesan dakwah terkait ketauhidan yang disajikan dengan pendekatan ilmu pengetahuan terkait sangat penting untuk dikembangkan dalam konteks masyarakat modern Indonesia.

Dari fenomena masalah, khususnya yang terjadi pada umat Islam Indonesia, dapat diketahui bahwa nilai-nilai rasional, berpikir ilmiah, dan kecintaan terhadap ilmu pengetahuan juga menjadi salah satu penyebab masalah umat Islam. Selama ini ajaran Islam sebagai al-khayr, hanya dipahami secara tekstual atau aspek kebahasaan, dengan berpusat pada persoalan fikih saja. Akibatnya ajaran Islam terlihat sempit dan kaku. Kebaikan dan universalitas ajaran Islam tidak nampak. Dalam menyikapi hal tersebut, masyarakat modern cenderung mengambil langkah memisahkan, agama adalah keyakinan dan urusan pribadi. Padahal jika menilik pesan dakwah dalam Alquran sangat jelas betapa umat Islam diperintahkan untuk iqra', berpikir, meneliti, sehingga dari situ bisa menghasilkan ilmu pengetahuan dan memahami kebesaran Tuhannya. Oleh karenanya pesan dakwah terkait ajaran Islam yang rasional, memerintahkan untuk berpikir, dan mencari ilmu pengetahuan menjadi pesan dakwah yang prioritas bagi masyarakat modern Indonesia.

Selain itu, menilik watak masyarakat Indonesia yang plural, maka juga perlu dikembangkan suatu sajian pesan dakwah yang menekankan pada kerukunan, toleransi serta menghargai perbedaan, dan nilai-nilai kebangsaan. Masyarakat Indonesia adalah masyarakat kesepakatan (gotong royong), umat Islam Indonesia sebagai bagian dari bangsa Indonesia telah bersepakat untuk bersama-sama dengan saudara sebangsa lainnya menjadi satu identitas Indonesia dan maju bersama. Nilai kebangsaan, kerukunan, toleransi, dan penghargaan terhadap perbedaan adalah modal penting untuk menjaga persatuan masyarakat Indonesia di tengah perbedaannya. Umat Islam sebagai mayoritas perlu menyadari dan menyuarakan hal tersebut menjadi satu bagian pesan dakwah aspek muamalah dalam konteks kehidupan berbangsa dan bernegara di Indonesia. Hal tersebut penting mengingat, sampai saat ini masih ada kelompok-kelompok organisasi dakwah tertentu (seperti gerakan Islam transnasional) yang menyuarakan pesan dakwah secara eksklusif, tidak mau menghargai perbedaan, menganggap saudara sebangsanya yang berbeda agama bahkan sesama agama tetapi beda kelompok adalah golongan nonmuslim, dan sebagainya.

Dengan demikian gambaran sajian pesan dakwah dengan pendekatan rasional pada masyarakat modern Indonesia adalah 
berikut, pertama, pesan atau materi dakwah harus disajikan dengan pendekatan ilmu pengetahuan dan kental dengan nuansa pertanggungjawaban (ilmiah). Dalam penyusunannya (desain materi), subjek dakwah atau dai juga harus bersikap objektif dan kritis terhadap ilmu pengetahuan yang dijadikan landasan. Hal tersebut agar tidak asal menggunakan landasan teori, tetapi dapat mempertanggungjawabkan penggunaan teori tersebut. Pemilihan ilmu pengetahuan atau teori yang digunakan bergantung dari variabel-variabel pembahasan dalam materi dakwah. Kedua, pesan dakwah perlu disajikan secara sistematis dan terkurikulum. Sistematis artinya terstruktur, ada pijakan yang jelas dalam setiap pembahasannya, sehingga alur logika pembahasan dapat dipertanggungjawabkan. Terkurikulum maksudnya terprogram, terencana, bukan sekali pertemuan selesai, tetapi beberapa pertemuan atau pembahasan materi, sesuai dengan problematika yang hendak dijawab melalui materi dakwah. Ketiga, isi pesan dakwah berdasarkan analisis masalah masyarakat Indonesia maka memprioritaskan pada tema-tema Ketauhidan, nilai berpikir (rasio) dalam Islam, masalah-masalah kerukunan hidup, toleransi, dan kebangsaan, bukan hanya persoalan fikih, ibadah ritual, maupun halhal yang sekadar berorientasi masa lalu.

\section{Metode Dakwah}

Karakteristik pertanggungjawaban yang berbasis pengetahuan rasional, baik secara filosofismaupun ilmu pengetahuan ilmiah dalam melaksanakan ajaran agama Islam, menjadi prinsip dasar di dalam membangun metode dakwah modern yang sangat relevan dengan karakteristik masyarakat modern. Sehingga bukan lagi dakwah yang bergaya dogmatis (doktrin) dengan bahasa yang normatif tekstual, maupun dengan menjustifikasi praktik-praktik masa lalu tanpa didasari kontekstualitasnya. Metode dakwah yang seperti ini berpotensi mematikan fungsi nalar serta proses dakwah yang lebih dialogis dan kritis (pemahaman konsep sami'na wa atha'na [kami dengar, kami taat] yang tidak pada tempatnya). Walaupun teks suci Alquran sebagai rujukan dakwah sudah final, tidak akan turun wahyu lagi, akan tetapi kenyataan akan terus berkembang dan menantang untuk direspon, dan selama manusia berada di dunia ini, persoalan dan tantangan tidak akan final (al-an-nushush qad intahat wa Alwaqi'ie la tantahi). Tantangan bagi para dai adalah memiliki sikap kreatif, dan inovatif, melalui ijtihad rasional dalam menjawab tantangan masa depan. ${ }^{65}$

Alquran surah An-Nahl ayat 125, menjadi pilar penting di dalam berdakwah, karena Allah telah memberikan tiga pijakan dasar dalam metode dakwah yang universal bagi dai dalam menghadapi mad'uw (khalayak dakwah). Pijakan tersebut adalah, pertama, landasan sosio-epistemologis dengan metode bil hikmah (pemikiran rasional, logis, filosofis) sesuai konteks permasalahan pemikiran yang dihadapi masyarakat modern (mad'uw) dengan pendekatan rasional yang dapat dipertanggungjawabkan secara filosofis, saintis dan teknologis. Pada prinsipnya, metode bil hikmah adalah metode yang menekankan penggunaan kekuatan akal pikiran dalam menghadapi realitas dakwah (mad'uw) dalam konteks

${ }^{65}$ Muhyiddin dan Syafei, Metode Pengembangan., 72. 
masyarakat modern. Kedua, landasan sosiopsikologis dengan metode mau'idzatul hasanah, sesuai konteks permasalahan kejiwaan, khususnya efek patologi kejiwaan yang sering dihadapi masyarakat modern, seperti kehampaan jiwa, keterasingan (alienasi) dan sejenisnya. Ketiga, landasan sosio-etis dengan metode billati hiya ahsan ketika mengomunikasikan dakwah, sesuai konteks permasalahan dan tantangan dai dalam mendakwahkan Islam di tengahtengah masyarakat modern, dengan tetap berpegang pada prinsip-prinsip social-etic tanpa mengurangi bobot kebenaran Islam yang disampaikan. Sehingga dai tidak hanya dibekali kemampuan teknis komunikasi dakwah akan tetapi juga etika komunikasi dakwah dengan mad'uw, yang dalam konteks masyarakat modern cenderung heterogen, baik dalam hal etnis, kultur, dan ras, bahkan mungkin berbeda agama. Implementasi dari metode ini adalah bagaimana mendakwahkan ajaran-ajaran Islam secara kultural, yang sejuk, ramah, mengayomi dan melindungi, tanpa kekerasan, tanpa hujatan dan fitnah, yang dapat merusak sendi-sendi kehidupan masyarakat modern, khususnya dalam konteks Indonesia. Ketiga prinsip metodologis tersebut merupakan satukesatuan yang berjalin kelindan dalam satu tarikan nafas dakwah Islam, yakni Islam yang rasional, Islam yang rahmatan lil 'alamin.

Dengan demikian secara teknis, metode dakwah pada konteks masyarakat modern juga dapat menggunakan berbagai metode dakwah pada umumnya, seperti ceramah, diskusi, tanya jawab, observasi realitas, keteladanan, dan sebagainya. Yang menjadi titik tekan dalam proses penyampaian pesan kepada mad'uw dengan karakteristik masyarakat modern adalah dai perlu memberikan ruang bagi mereka untuk menyampaikan gagasan/ide, pertanyaan, sikap, dan sebagainya terkait pesan dakwah. Yang itu bisa dilakukan dengan membuka sesi tanya jawab baik di forum, kelompok kecil, maupun personal, membuka diskusi, dan dialog, yang pada prinsipnya proses transformasi gagasan dan informasi tidak hanya berlangsung satu arah, melainkan dua arah. Sehingga sekalipun menggunakan teknik ceramah dalam metode dakwahnya, namun tetap membuka sesi tanya jawab. Demikian pula, ketika dai menggunakan metode observasi atau keteladanan, juga tetap membuka ruang bagi mad'uw untuk bertanya, berdiskusi, dan berdialog. Dari situ, dai bisa menjelaskan dan memberikan arahan berupa pesan dakwah yang langsung menjawab kebutuhan dan permasalahan mad'uw. Disediakannya ruang bagi mad'uw untuk menyampaikan gagasannya adalah sejalan dengan karakteristik masyarakat modern yang lebih terbuka dan rasional. Ketika menerima materi dakwah sangat dimungkinkan bagi manusia modern melibatkan pemikirannya secara aktif, dari situ memunculkan berbagai pertanyaan, ataupun gagasan-gagasan yang merefleksikan pengalaman dan pengetahuannya. Sehingga semangat metode dakwah bil hikmah dengan menyentuh akal mad'uw manusia modern dapat terimplementasi dengan dibukanya ruang dialog dalam proses dakwah.

Secara operasional penentuan metode dakwah sampai dengan tingkat teknis dan taktis di lapangan pada masyarakat modern memerlukan upaya pemahaman yang lebih spesifik terhadap masyarakat atau kelompok masyarakat modern yang menjadi mad'uw. Terlebih dalam konteks Indonesia, yang masyarakat modernnya juga beragam, 
dari segi kultur, bahasa, tingkat penerimaan terhadap modernitasnya, dan sebagainya. Sehingga tiap daerah di Indonesia bisa memiliki ciri khas kemodernan yang berbeda dengan wilayah lainnya. Untuk itu metode dakwah pada masyarakat modern Indonesia yang spesifik memerlukan riset terhadap perilaku pasar yang menjadi mad'uw sasaran dakwah. Dai pada masyarakat modern Indonesia tidak bisa mengoperasionalkan metode dakwah yang sama pada suatu kelompok masyarakat modern dengan kelompok masyarakat lainnya. Keragaman masyarakat modern Indonesia mengharuskan para dai untuk menghindari metode-metode dakwah yang memaksa, menggunakan kekerasan, hujatan, dan fitnahan terhadap kelompok lain. Sebab selain tidak sejalan dengan nilainilai toleransi yang diperlukan dalam konteks kehidupan berbangsa juga akan merugikan pelaku dakwah itu sendiri. Masyarakat modern akan melihat bahwa, pelaku dakwah yang menggunakan caracara tidak etis (segala cara) adalah sebagai suatu hal yang keliru, dan akan dihindari. Terlebih dengan watak kebebasan dan keterbukaannya, manusia modern tidak akan mau dipaksa, apalagi menggunakan kekerasan. Hal ini sejalan dengan landasan sosio-etis dalam pengembangan metode dakwah pada masyarakat modern.
Sehingga bisa disimpulkan, pertama, secara prinsip metode dakwah pada masyarakat modern tetap berpijak pada landasan sosioepistemologis, sosio-psikologis, dan sosioetis yang merupakan pengejawantahan dari prinsip dakwah qurani. Kedua, secara teknis beragam metode dakwah dapat digunakan pada konteks masyarakat modern, hanya perlu ditekankan bagi tersedianya ruang diskusi dan dialog bagi manusia modern yang menjadi mad'uw. Implikasinya metode dakwah pada masyarakat modern harus menghindari cara-cara doktrin dan satu arah. Ketiga, operasionalisasi metode dakwah pada masyarakat modern Indonesia memerlukan pemahaman mendalam terhadap karakter masyarakat modern secara spesifik yang menjadi mad'uw. Keempat, para pelaku dakwah pada masyarakat modern konteks Indonesia dalam pelaksanaan metode dakwahnya harus melandasakan pada etis dakwah, menghindari penggunaan segala cara dan kekerasan, serta tetap mengedepankan toleransi dan persatuan Indonesia.

Berikut sketsa hasil analisis pendekatan rasional dalam penyajian pesan dan metode dakwah pada masyarakat modern Indonesia: 


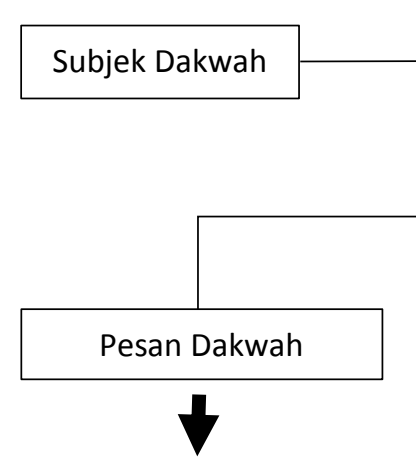

1. Disajikan dengan pendekatan ilmu pengetahuan dan pertanggungjawaban ilmiah.

2. Disajikan secara sistematis dan terkurikulum, sesuai dengan problematika masyarakat yang hendak dijawab melalui materi dakwah.

3. Isi pesan dakwah memprioritaskan:

- Ketauhidan

- Nilai berpikir dan ilmu pengetahuan dalam Islam

- Kerukunan hidup, toleransi, dan kebangsaan.
Mitra Dakwah

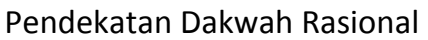

Metode Dakwah

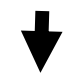

1. Berpijak pada landasan sosioepistemologis, sosio-psikologis, dan sosio-etis.

2. Secara teknis dapat menggunakan berbagai metode dakwah sebagaimana umumnya (ceramah, diskusi, tanya jawab, observasi, keteladanan, dan lain-lain)

3. Pada prinsipnya perlu membuka ruang dialog/diskusi dalam proses dakwah, dan menghindarkan doktrin, pemaksaan, dan kekerasan.

4. Menjunjung etika dakwah, tidak segala cara, mengedepankan toleransi, dan persatuan bangsa
Masyarakat Modern Indonesia:

1. Karakteristik umum masyarakat modern:

- Terbuka terhadap hal baru/perubahan

- Percaya pada ilmu pengetahuan

- Rasional, dan lain-lain

2. Konteks Keindonesiaan:

- Majemuk/heterogen

- Religius

- Konsepsi kebangsaan

3. Problematika:

- Gejala negatif modernisme ala Barat

- Patologi sosial

- Kesenjangan ekonomi

- Politik segala cara, dan lainlain

Sketsa 1 - Hasil Analisis Pendekatan Rasional dalam Penyajian Pesan dan Metode Dakwah pada Masyarakat Modern Indonesia

\section{Kesimpulan}

Dakwah pendekatan rasional adalah jalan untuk menjawab tantangan zaman, yang mengharuskan para pelaku dakwah menggunakan cara-cara baru yang lebih kontekstual dan adaptif terhadap problematika dan karakter mad'uw yang dihadapi. Dalam konteks Indonesia, modernitas telah menjadi bagian masyarakat Indonesia, yang tampil dengan corak yang beragam, dengan berbagai efek positif dan negatifnya. Dalam konteks inilah dakwah pendekatan rasional menemukan momentumnya untuk diimplementasikan guna menjawab problematika yang dihadapi manusia modern Indonesia. Studi ini memfokuskan pada penyajian pesan dan pemilihan metode dakwah yang berbasis pendekatan rasional untuk diterapkan dalam konteks masyarakat modern kontemporer Indonesia. Rasionalitas penyajian pesan dakwah untuk masyarakat modern Indonesia di antaranya adalah penyajian pesan atau materi dakwah harus dapat dipertanggungjawabkan dan berpijak pula pada ilmu pengetahuan terkait, pesan dakwah juga perlu disajikan secara sistematis dan terkurikulum. Pada aspek isi pesan dakwah, dalam konteks sekarang diprioritaskan pada tema-tema ketauhidan, 
nilai berpikir, dan moderasi kebangsaan. Adapun rasionalitas metode dakwah pada masyarakat modern Indonesia, di antaranya adalah tetap berpijak pada landasan sosioepistemologis, sosio-psikologis, dan sosioetis yang diimplementasikan sesuai dengan karakter dan problematika masyarakat modern Indonesia. Dalam tataran teknis dan operasional, metode dakwah dapat dilakukan dengan beragam cara dengan berpijak pada pemahaman yang mendalam terhadap karakter masyarakat atau kelompok masyarakat atau personal manusia modern Indonesia yang menjadi mad'uw. Hal yang perlu ditekankan dalam setiap operasionalisasi metode dakwah pada masyarakat modern adalah penyediaan ruang dialog dan diskusi, sehingga menghindari cara-cara doktriner dan pemaksaan. Dalam pelaksanaanya, para pelaku dakwah pada masyarakat modern perlu menjunjung tinggi etika dakwah, yaitu dengan tidak melakukan segala cara, fitnah, pemaksaan, apalagi kekerasan. Sebaliknya justru mengedepankan dakwah kultural yang santun, sejuk, dan ramah, serta tetap menjaga nilai-nilai persatuan dan kesatuan bangsa.

Oleh karenanya studi ini merekomendasikan bagi para pelaku dakwah di masyarakat modern untuk mulai menjadikan pendekatan dakwah rasional sebagai alternatif dalam pelaksanaan dakwahnya. Pesan-pesan dakwah disusun sedemikian rupa sesuai dengan permasalahan utama yang dihadapi masyarakat. Metode dakwah yang dikembangkan menjauhi cara-cara doktriner dan pemaksaan, tetapi membuka ruang dialog dan diskusi, dengan cara-cara yang baik dan sejuk. Secara akademik kajian dakwah pendekatan rasional, masih perlu untuk terus dikembangkan dalam berbagai tema-tema kajian, baik yang bersifat paradigmatik, metodologis, maupun teknis.

\section{Bibliografi}

Al-Faruqi, Ismail Raji dan Al-Faruqi, Lois Lamya. Atlas Budaya Islam Menjelajah Khazanah Peradaban Gemilang. Penerjemah Ilyas Hasan. Bandung: Mizan, 1998.

Alhidayatillah, Nur. "Dakwah Dinamis di Era Modern," Jurnal An-Nida', Volume 41, Nomor 2, (Desember, 2017): 265-276.

Al-Warisyi, Iskandar. Dakwah Illahiyah: Jalan dakwah Tujuh Rasul Allah dalam Memperbaiki Masyarakat Jahiliyah. Surabaya: Penerbit Yayasan Al-Kahfi, 2009. . Kedudukan Akal dan Wahyu dalam Islam. Surabaya: Penerbit Yayasan Al-

Kahfi, 2012.

Anis, Muhammad. "Spiritualitas di Tengah Modernitas Perkotaan," Jurnal Bayan, Volume 2, No. 4, (2013): 1-15.

Arifin, Anwar. Dakwah Kontemporer, Sebuah Studi Komunikasi. Yogyakarta: Graha Ilmu, Cetakan ke-1, 2011.

Aripudin, Acep. Sosiologi Dakwah. Bandung: Rosda, 2013.

Asmaya, Enung. "Modernitas dan Tantangannya terhadap Pelaksanaan Dakwah," Komunika, Volume 3, Nomor 1. (Januari-Juni 2009): 46-62.

Aswadi. Dakwah Progresif Perspektif Allquran. Sidoarjo: Dwiputa Pustaka Jaya, 2016. 
Aziz, Moh. Ali. Ilmu Dakwah Edisi Revisi. Jakarta: Kencana, 2016.

Basit, Abdul. "Dakwah Cerdas di Era Modern" Jurnal Komunikasi Islam, Volume 03, Nomor 01, (Juni 2013): 90-91. Filsafat Dakwah. Jakarta: Rajagrafindo Persada, 2013.

Wacana Dakwah Kontemporer. Editor: Abdul Wachid. Yogyakarta: STAIN Purwokerto \& Pustaka Pelajar, 2005.

Bastomi, Hasan. "Keteladanan sebagai Dakwah Kontemporer dalam Menyongsong Masyarakat Modern," Komunika, Volume 11, Nomor 1, (Januari - Juni 2017): 1-19.

Giddens, Anthony. The Consequences of Modernity. California: Stanford University Press, 1990. Hidayat, Ahmad. "Efek Dakwah Persuasif," Jurnal Kajian dan Pengembangan Manajemen Dakwah, Volume 02, Nomor 01, (Juni, 2012): 39-56.

Hilmy, Masdar. Islam Profetik - Substansi Nilai-Nilai Agama dalam Ruang Publik. Yogyakarta: Kanisius, 2008.

Hodgson, Marshal G.S. The Venture of Islam: Iman dan Sejarah dalam Peradaban Dunia Masa Klasik. Buku Pertama: Lahirnya Sebuah Tatanan Baru. Jakarta: Paramadina, 1999.

Ilaihi, Wahyu. Komunikasi Dakwah. Bandung: PT. Remaja Rosdakarya, 2010.

Ismail, A. Ilyas dan Hotman, Prio. Filsafat Dakwah: Rekayasa Membangun Agama dan Peradaban Islam. Jakarta: Kencana, 2011.

Jati, Wasisto Raharjo. "Sufisme Urban: Konstruksi Keimanan Baru Kelas Menengah Muslim" Jurnal Kajian dan Pengembangan Manajemen Dakwah, Vol. 5 No.2 (Des 2015): 175-192 Kartasasmita, Ginandjar. "Karakteristik dan Struktur Masyarakat Indonesia Modern" Sarasehan Uji Sahih atas Pokok-pokok Pikiran tentang GBHN 1998. Yogyakarta, 29 Juni 1997.

$\mathrm{KBBI}$ versi online/daring, kbbi.web.id./dekat.html.

Inkeles, Alex and Smith, David H. Becoming Modern. Cambridge: Harvard Universit Press, 1974. Madjid, Nurcholish. Islam Doktrin dan Peradaban, Sebuah Telaah Kritis tentang Masalah Keimanan, Kemanusiaan dan Kemodernan. Jakarta: Paramadina, 2000. . Islam Kemodernan, dan Keindonesiaan. Bandung: Mizan, 1997.

Miles, Matthew B. \& Huberman, Michael A. Qualitative Data Analysis, A Sourccebook of New Methods. London, Beverly Hills: Sage Publications, 1984.

Muhiddin, Asep. Dakwah dalam Perspektif Alquran. Bandung: Pustaka Setia, 2002.

Muhyiddin, Asep dan Syafei, Agus Ahmad. Metode Pengembangan Dakwah. Bandung: CV. Pustaka Setia. Cet. 1, 2002.

Naisbitt, John. High Tech, High Touch: Technology and Our Search for Meaning. New York: Broadway, 1999.

Nasution, Harun. Akal dan Wahyu dalam Islam. Jakarta: UI Press, 1986. Islam Rasional: Gagasan dan Pemikiran. Editor Saiful Muzani. Bandung: Mizan, 2000.

Pimpinan MPR dan Tim Kerja Sosialisasi MPR Periode 2009-2014. Empat Pilar Kehidupan Berbangsa dan Bernegara. Jakarta: Sekretariat Jendral MPR RI, 2012.

Poespoprodjo, W. \& Gilarso, EK. T. Logika Ilmu Menalar. Bandung: Pustaka Grafika, 1999.

Prasetia, Bagus Wira. "Metode Komunikasi Dakwah pada Media Sosial (Facebook, Youtube, Twitter, dan Instagram)," Jurnal Kajian dan Pengembangan Manajemen Dakwah, Volume 08, Nomor 02, (Desember 2018): 403-424. 
Rahmat, Ihsan dan Kusuma, Bayu Mitra A. "Menembus Batas Kajian Doktrinal” Pengantar Editor dalam Ridla, M. Rosyid; Rifa'i, Afif; dan Suisyanto, Pengantar Ilmu Dakwah: Sejarah, Perspektif, dan Ruang Lingkup. Yogyakarta: Samudra Biru, 2017.

Rakhmawati, Istina. "Paradigma Dakwah Upaya Merespon Problematika Umat Islam," AtTabsyir: Jurnal Komunikasi Penyiaran Islam, Volume 3, Nomor 2, (Desember, 2015): 405-426.

Schoorl, J. W. Modernisasi - Pengantar Sosiologi Pembangunan Negara-Negara Sedang Berkembang. Penerjemah: R.G. Soekadijo. Jakarta: Gramedia Pustaka Utama, 1991.

Shihab, M. Quraish. Membumukan Al-Quran: Fungsi dan Peran Wahyu Dalam Kehidupan Masyarakat. Bandung: Mizan, 1995.

Suparta, Mundzir dan Hefni, Harjani (ed). Metode Dakwah. Jakarta: Prenada Media, 2003.

Suriasumantri, Jujun S. Filsafat Ilmu: Sebuah Pengantar Populer. Jakarta: Sinar Agape Press, 1985.

Wahid, Abdurrahman (Ed.). Ilusi Negera Islam - Ekspansi Gerakan Islam Transnasional di Indonesia. Jakarta: The Wahid Institute, 2010. 
Suwari \& Dedy Pradesa

26 | INTELEKSIA - Jurnal Pengembangan IImu Dakwah 